\title{
Quality evaluation of tithonia (Tithonia diversifolia) with fermentation using Lactobacillus plantarum and Aspergillus ficuum at different incubation times
}

\author{
RONI PAZLA ${ }^{1, \vartheta}$, NOVIRMAN JAMARUN ${ }^{1, \bullet \bullet}$, MARDIATI ZAIN ${ }^{1}$, GUSRI YANTI $^{2}$, RIKI HISKIA CHANDRA ${ }^{3}$ \\ ${ }^{1}$ Department of Nutritional Science and Feed Technology, Faculty of Animal Husbandry, Universitas Andalas. Jl. Unand, Limau Manis Campus, Padang \\ 25163, West Sumatra, Indonesia. Tel./fax.: +62-751-71464, ^email: ronipazla@ansci.unand.ac.id, •vemail: novirman55@gmail.com \\ ${ }^{2}$ Doctoral Program, Faculty of Animal Husbandry, Universitas Andalas. Jl. Unand, Limau Manis Campus, Padang 25163, West Sumatra, Indonesia \\ ${ }^{3}$ Graduate Program, Faculty of Animal Husbandry, Universitas Andalas. J1. Unand, Limau Manis Campus, Padang 25163, West Sumatra, Indonesia
}

Manuscript received: 19 July 2021. Revision accepted: 26 August 2021.

\begin{abstract}
Pazla R, Jamarun N, Zain M, Yanti G, Chandra RH. 2021. Quality evaluation of tithonia (Tithonia diversifolia) with fermentation using Lactobacillus plantarum and Aspergillus ficuum at different incubation times. Biodiversitas 22: 3936-3942. This research aimed to evaluate the nutritional quality of tithonia (Tithonia diversifolia) fermented using Lactobacillus plantarum and Aspergillus ficuum with different incubation times on nutritional content, digestibility, phytase enzyme activity, and characteristics of rumen fluid. The research used an experimental method with a factorial completely randomized design to evaluate the nutritional content and phytase enzyme activity after fermentation (stage 1). A randomized block design was used to evaluate in vitro digestibility and rumen fluid characteristics (stage 2). For factorial completely randomized design, factor A is the type of microbe ( $L$. plantarum and A. ficuum), then factor B is the incubation time (3,5,7 days). Parameters observed were the nutritional content of dry matter (DM), organic matter $(\mathrm{OM})$, crude protein $(\mathrm{CP})$, crude fiber $(\mathrm{CF})$, and phytase enzyme activity. For the Randomized Block Design, the research treatments were $\mathrm{A}=A$. ficuum +5 days of incubation, $\mathrm{B}=$ A. ficuum +7 days of incubation, $\mathrm{C}=$ L. plantarum +3 days of incubation, $\mathrm{D}=$ L. plantarum +5 days of incubation. Parameters measured were the digestibility of dry matter(DMD), organic matter (OMD), crude protein (CPD), crude fiber (CFD), rumen $\mathrm{pH}$, VFA production, and $\mathrm{NH}_{3}$ rumen fluid. The results showed that there was an interaction between the type of microbe and incubation time. The treatment had a significantly different effect $(\mathrm{P}<0.05)$ on the content of OM, CP, CF and phytase enzyme activity, but no interaction with the content of DM treatment. In the digestibility, the results showed that the effect was not significantly different $(\mathrm{P}>0.05)$ on DMD, OMD, CPD but had a significant effect $(\mathrm{P}<0.05)$ on CFD. The treatments also had no significant effect $(\mathrm{P}>0.05)$ on VFA but were significantly different $(\mathrm{P}<0.05)$ on $\mathrm{NH}_{3}$. From this study, it can be concluded that fermented tithonia using A. ficuum with an incubation period of 7 days could improve the quality of tithonia. It can be seen from the content of CP (31.02\%), CF (16.52\%), phytase enzyme activity (37.36 U/ml), DMD (66.86\%), OMD (67.36\%), CFD (81.01\%), CPD (70.37\%), VFA production $135 \mathrm{mM}$ and $\mathrm{NH}_{3}$ concentration $14.31 \mathrm{mg} / 100 \mathrm{ml}$, and $\mathrm{pH}$ value 6.72 which is suitable for rumen microbial growth.
\end{abstract}

Keywords: Aspergillus ficuum, digestibility, enzyme activity, fermentation, L. plantarum, Tithonia diversifolia

\section{INTRODUCTION}

Forage is the primary source of feed for ruminants. Forage feed serves to meet the needs of livestock both for basic life, growth, reproduction, and production. Ruminant livestock that experiences a shortage of forage feed ingredients will be stunted in the growth process. Various efforts to increase livestock production to meet animal protein sources' needs will be challenging if the availability of forage is not proportional to the needs and existing livestock population. One of the efforts to overcome the shortage of forage feed ingredients is to look for alternative feeds with high nutritional content, high production, and easy to adapt. One type of plant that can be used is tithonia (Tithonia diversifolia).

Tithonia can grow along roads, lakesides, on the edge of rice fields, and vacant land not used by the community (Arief et al. 2019; Arief et al. 2020). This plant has large roots, many branches, a soft trunk and overgrows so that in a short time, it can form a dense bush. Hafis (2019) stated that tithonia plants harvested six times a year can produce
4.10 tons/ha-10.20 tons/ha dry biomass production or 24.00-46.80 tons/ha/year fresh production. Tithonia as animal feed has not been widely used; this is because there is not much information about the use of these plants as animal feed. Also, tithonia is often considered a weed so that it is thrown away, even though it has a fairly good nutritional content. The nutritional content of whole tithonia (leaves + stems) are dry matter (DM), (25.57\%), organic matter (OM), (84.01\%), crude protein (CP), (22.98\%), and crude fiber (CF), (18.17\%) (Jamarun et al. 2017a). Therefore, tithonia has good potential to be used and developed as forage feed because it has good nutritional content and high productivity.

The obstacle to using tithonia for animal feed is antinutritional substances such as phytic acid, tannins, saponins, oxalate, alkaloids, and flavonoids (Aye 2016). These limiting factors, both substances directly contained in feed ingredients or through metabolic products in livestock, can interfere with the use of feed. Also, it can affect the health and production of animals through mechanisms of decreasing nutrient intake, digestive and 
absorption disorders and causing other adverse side effects. Oluwasola and Dairo (2016) stated that the most antinutrient content in tithonia was phytic acid, 79.2 $\mathrm{mg} / 100 \mathrm{gr}$. The high phytic acid content in tithonia causes a bitter taste, so it is not liked by livestock. Phytic acid in a material can also interfere with mineral absorption because phytic acid has chelating agent properties that can bind minerals so that the biological availability of these minerals decreases. Phytic acid can also bind to proteins and carbohydrates so that the digestion and absorption of these nutrients are disturbed (Selle et al. 2021).

Various processing methods can be used to reduce antinutritional substances in feed ingredients, one of which is through fermentation technology. Fermentation is the process of breaking down organic compounds into simple ones involving microorganisms. The fermentation process can increase food substances such as protein and energy and break down complex components into simple components (Jamarun et al. 2017b). Fermentation can also increase the nutritional value of low-quality ingredients and function in preserving feed ingredients, and one way to remove antinutrients or toxins contained in feed ingredients.

Microbes that can be used for fermentation in tithonia are Lactobacillus plantarum bacteria and Aspergillus ficuum mold. These microbes produce a phytase enzyme (Myo-inositol hexakisphosphate phosphohydrolase) which can hydrolyze phytic acid (myo-inositol hexakisphosphate) into inorganic monophosphate. Also, it can hydrolyze low myo-inositol and some into free Myo-inositol. Therefore, the nutrients bound by phytic acid can be utilized. Sumenger et al. (2013) reported that L. plantarum could produce high intracellular and extracellular phytase enzymes. Susana et al. (2000) also said that A. ficuum had high activity and production of phytase enzymes from 60 isolates collected. Fermentation applications of A. ficuum and $L$. plantarum to reduce the phytic acid content in tithonia have not been carried out. The selection of these microbes in this study is because these microbes are relatively safe, not pathogenic, and have been widely applied in fermentation.

Fermentation time is also one of the factors that must be considered in making fermented feed. The fermentation that is too short resulted in limited opportunities for microorganisms to grow. The substrate components that can be remodelled into cell mass will also be small; for this reason, proper fermentation time is needed so that microorganisms have more opportunities to grow and reproduce. The ability of microorganisms to grow and develop will affect the quality of a feed ingredient physically, chemically, and biologically. Therefore, by knowing the adequate time for the development of microorganisms, we can get the best fermentation results in terms of quality. This study aimed to evaluate the quality of fermented tithonia using L. plantarum and A. ficuum with different fermentation times in vitro.

\section{MATERIALS AND METHODS}

\section{Sample collection and nutrient analysis}

Tithonia was taken in the Koto Lalang agricultural land area, Kuranji, Padang City, West Sumatra Province. For the fermentation process, In-vitro treatment and chemical analysis were carried out at the Feed Industry and Technology Laboratory, Ruminant Nutrition Laboratory, and Biotechnology Laboratory from Andalas University, Padang, Indonesia. Proximate analysis was carried out based on the (AOAC 2010) method. In vitro test using the method of Tilley and Terry (1963). Phytase enzyme activity follows the Alltech method with some modifications (Shieh and Ware 1968).

\section{Rejuvenation of Aspergillus ficuum and Lactobacillus plantarum}

The rejuvenation of $A$. ficuum was carried out on potato dextrose agar sloping media, incubated at $30{ }^{\circ} \mathrm{C}$ for seven days. In contrast, L. plantarum was grown on MRS Broth media at $37^{\circ} \mathrm{C}$ for 48 hours. The MRS Broth media was weighed as much as 5.52 grams and then added $100 \mathrm{ml}$ of distilled water, heated until it was clear on a hot plate. Cover with cotton and aluminum foil, then sterilize using an autoclave at $121^{\circ} \mathrm{C}$ for 30 minutes. Then cool and inoculate with $1 \mathrm{ml}$ of the bacterial parent. Incubate in an incubator at $37^{\circ} \mathrm{C}$.

\section{Titonia fermentation process}

One hundred grams of tithonia flour was put into a plastic bag and added with distilled water until the water content reached $60 \%$ and then homogenized. Sterilize in an autoclave for 30 minutes at a temperature of $121^{\circ} \mathrm{C}$. After the medium has cooled, $10 \%$ of the sample weight has been inoculated with microbes and $5 \mathrm{ml}$ for L. plantarum, then stored in a sterile room. Then, samples were harvested after 3,5 and 7 days and weighed fresh, then in the oven to dry at $60^{\circ} \mathrm{C}$. If it is dry, the medium is stored and ready for the next stage, namely proximate analysis and In-vitro digestibility testing.

\section{Research design}

Stage 1; the research method used to evaluate the chemical composition of post-fermentation tithonia, is an experimental method with a randomized completely design with a factorial pattern of $2 \times 3$ with three replications. The parameters measured were dry matter, organic matter, crude protein, crude fiber, and phytase enzyme activity. The research treatment is as follows:

The first factor is the addition of microorganisms (A):

$\mathrm{A} 1=$ Tithonia + L. plantarum

A2 $=$ Tithonia + A. ficuum

The second factor is the length of fermentation (B):

$\mathrm{B} 1=3$ days

$\mathrm{B} 2=5$ days

B3 $=7$ days

Stage 2; the experimental design used in the in vitro test was a randomized block design with four treatment combinations and three groups (rumen fluid collection) as replication. The treatment in this second stage was based 
on the results of the best nutritional value (4 best treatments) in stage one. The parameters measured were dry matter digestibility (DMD), organic matter digestibility (OMD), crude protein digestibility (CPD), crude fiber digestibility (CFD), total VFA concentration, $\mathrm{NH}_{3}$ concentration, and rumen fluid $\mathrm{pH}$.

The treatments tested are:

A: Fermented tithonia with A. ficuum for five days

B: Fermented tithonia with A. ficuum for seven days

C: Fermented tithonia with L. plantarum for three days

D: Fermented tithonia with $L$. plantarum for five days

Data were analyzed using analysis of variance (ANOVA) according to (Steel and Torrie 2002). If the study of variance results shows a significant effect, further tests are carried out with Duncan's Multiple Range Test.

\section{RESULT AND DISCUSSION}

\section{Dry matter content of fermented tithonia}

The dry matter content of fermented tithonia with different microbes and incubation time for each treatment is presented in Table 1 .

The analysis of variance showed no interaction between the treatment of different types of microbes and incubation time on the DM content of fermented tithonia. However, every microbial treatment and incubation time showed a significant effect $(\mathrm{P}<0.05)$ on $\mathrm{DM}$ content. DMRT test results showed that the DM content of the A1 ( $L$. plantarum $)$ treatment showed a significant impact $(\mathrm{P}<0.05)$ with the $\mathrm{A} 2$ (A. ficuum) treatment. Incubation time in treatment B1 (3 days incubation) showed significantly different results $(\mathrm{P}<0.05)$ with treatment $\mathrm{B} 2 \quad(5$ days incubation) and treatment B3 (7 days incubation), while treatment B2 (5 days incubation) showed similar results, not significantly different $(\mathrm{P}>0.05)$ with treatment B3 (7 days incubation).

The difference DM content in treatments A1 and A2 was associated with the type and ability of each different microbe in fermenting a material. Bacteria have a faster growth at optimum conditions when compared to molds, so that the ability to digest substrate is also more extraordinary. Bacteria as inoculum in the fermentation process takes less time than molds; bacteria have a more straightforward cell structure. So most bacteria have a shorter generation time when compared to molds whose cell structure is more complicated and the generation time is quite long (Saylor and Casale 2020).

The high DM content in treatments B1 was influenced by the short fermentation time. According to Mirnawati et al. (2010), the short fermentation time resulted in the substrate decomposition process not being optimal, so that the water content was low, and DM was still high. During the fermentation process, the substrate undergoes a decomposition process that causes changes in water content. Changes in DM occur due to evaporation, substrate hydrolysis, or metabolic water production.

\section{Organic matter content of fermented tithonia}

The organic matter content of fermented tithonia with different microbes and incubation time for each treatment is presented in Table 1 .

The analysis of variance showed an interaction $(\mathrm{P}<0.05)$ between different types of microbes and incubation time on $\mathrm{OM}$ content of fermented tithonia. Factor A (type of microbe) had an insignificant effect $(\mathrm{P}>0.05)$, but factor B (incubation time) has a significant impact $(\mathrm{P}<0.05)$ on the $\mathrm{OM}$ content of fermented tithonia. The results of the DMRT test showed that the OM content in the A2B1 treatment was significantly $(\mathrm{P}<0.05)$ higher than the A1B1, A1B2, A1B3, and A2B3 treatments. The high and low content of $\mathrm{OM}$ in the treatment is also made possible by microbial activity in the fermentation process, which causes the breakdown of the substrate content, making it easier for existing microorganisms to digest organic matter. The fermentation of organic matter releases fermented products in the form of sugar, alcohol, and amino acids caused by the activity of micro-services so that changes occur that affect the nutritional value. It is following the opinion of Putra et al. (2019), which states that the fermentation process carried out by microorganisms will cause changes that affect the nutritional value in which carbohydrates are converted into alcohol, organic acids, water, and $\mathrm{CO}_{2}$.

The decrease in OM content is due to the nutrients that have been utilized and remodelled by microbes. Microbial growth is closely related to the length of fermentation, where microbial development cycles start from the growth phase to the death phase. Mirnawati et al. (2013) added that the longer the fermentation time, the more food substances were overhauled.

Table 1. The phytochemical characteristic of fermented tithonia with different types of microbes and incubation time

\begin{tabular}{|c|c|c|c|c|}
\hline \multirow{2}{*}{$\begin{array}{c}\text { Factor A } \\
\text { (Types of microbes) }\end{array}$} & \multicolumn{3}{|c|}{ Factor B (incubation time) } & \multirow{2}{*}{ Average } \\
\hline & B1 & B2 & B3 & \\
\hline \multicolumn{5}{|l|}{ Dry matter } \\
\hline A1 & 90.17 & 89.86 & 89.49 & $89.84^{\text {B }}$ \\
\hline A2 & 91.76 & 91.26 & 90.12 & $91.05^{\mathrm{A}}$ \\
\hline Average & $90.96^{\mathrm{a}}$ & $90.56^{\mathrm{b}}$ & $89.8^{b}$ & 90.44 \\
\hline \multicolumn{5}{|l|}{ Organic matter } \\
\hline A1 & $87.78^{\mathrm{aA}}$ & $87.51^{\mathrm{abA}}$ & $87.04^{\mathrm{bA}}$ & 87.44 \\
\hline $\mathrm{A} 2$ & $88.40^{\mathrm{aB}}$ & $87.91^{\mathrm{aA}}$ & $86.67^{\mathrm{bA}}$ & 87.66 \\
\hline Average & $88 . .09^{\mathrm{a}}$ & $87.71^{\mathrm{a}}$ & $86.86^{\mathrm{b}}$ & 87.55 \\
\hline \multicolumn{5}{|l|}{ Crude protein } \\
\hline A1 & $29.01^{\mathrm{aA}}$ & $27.56^{\mathrm{bB}}$ & $24.30^{\mathrm{cB}}$ & $26.96^{\mathrm{B}}$ \\
\hline $\mathrm{A} 2$ & $27.25^{\mathrm{cB}}$ & $29.14^{\mathrm{bA}}$ & $31.02^{\mathrm{aA}}$ & $29.14^{\mathrm{A}}$ \\
\hline Average & 28.13 & 28.35 & 27.66 & 28.05 \\
\hline \multicolumn{5}{|l|}{ Crude fiber } \\
\hline A1 & $17.95^{\mathrm{aB}}$ & $17.37^{\mathrm{abA}}$ & $17.18^{\mathrm{bA}}$ & 17.50 \\
\hline $\mathrm{A} 2$ & $18.84^{\mathrm{aA}}$ & $16.75^{\mathrm{bA}}$ & $16.52^{\mathrm{bA}}$ & 17.37 \\
\hline Average & $18.40^{\mathrm{a}}$ & $17.06^{\mathrm{b}}$ & $16.85^{\mathrm{b}}$ & 17.44 \\
\hline \multicolumn{5}{|l|}{ Phytase activity } \\
\hline A1 & $9.12^{\mathrm{bB}}$ & $11.71^{\mathrm{aB}}$ & $6.68^{\mathrm{cB}}$ & $9.17^{\mathrm{B}}$ \\
\hline $\mathrm{A} 2$ & $28.37^{\mathrm{cA}}$ & $36.12^{\mathrm{bA}}$ & $37.46^{\mathrm{aA}}$ & $33.98^{\mathrm{A}}$ \\
\hline Average & $18.74^{\mathrm{c}}$ & $23.91^{\mathrm{a}}$ & $22.07^{\mathrm{b}}$ & 21.58 \\
\hline
\end{tabular}

Note: Values with different superscripts in the row (lower case) and columns (capital letters) are significant $(\mathrm{P}<0.05) . \mathrm{A} 1=L$. plantarum, $\mathrm{A} 2=A$. ficuum, $\mathrm{B} 1=3$ days, $\mathrm{B} 2=5$ days, $\mathrm{B} 3=5$ days 


\section{The crude protein content of fermented tithonia}

The crude protein content of fermented tithonia with different microbes and incubation time for each treatment is presented in Table 1.

The analysis of variance showed an interaction $(\mathrm{P}<0.05)$ between different types of microbes and incubation time on $\mathrm{OM}$ content of fermented tithonia. Factor A (type of microbe) had an insignificant effect $(\mathrm{P}>0.05)$, but factor $\mathrm{B}$ (incubation time) has a significant impact $(\mathrm{P}<0.05)$ on the $\mathrm{OM}$ content of fermented tithonia. The results of the DMRT test showed that the OM content in the A2B1 treatment was significantly $(\mathrm{P}<0.05)$ higher than the A1B1, A1B2, A1B3, and A2B3 treatments. The high and low content of $\mathrm{OM}$ in the treatment is also made possible by microbial activity in the fermentation process, which causes the breakdown of the substrate content, making it easier for existing microorganisms to digest organic matter. The fermentation of organic matter releases fermented products in the form of sugar, alcohol, and amino acids caused by the activity of micro-services so that changes occur that affect the nutritional value. It is following the opinion of Putra et al. (2019), which states that the fermentation process carried out by microorganisms will cause changes that affect the nutritional value in which carbohydrates are converted into alcohol, organic acids, water, and $\mathrm{CO}_{2}$.

The decrease in OM content is due to the nutrients that have been utilized and remodelled by microbes. Microbial growth is closely related to the length of fermentation, where microbial development cycles start from the growth phase to the death phase. Mirnawati et al. (2013) added that the longer the fermentation time, the more food substances were overhauled.

\section{The crude fiber content of fermented tithonia}

The crude fiber content of fermented tithonia with different types of microbes and incubation time for each treatment is presented in Table 1 .

The analysis of variance showed an interaction $(\mathrm{P}<0.05)$ between the types of microbes and the length of incubation time on the $\mathrm{CF}$ content of fermented tithonia. Factor A (type of microbe) had an insignificant effect ( $>0.05)$, but factor B (incubation time) had a significant effect $(\mathrm{P}<0.05)$ on the $\mathrm{CF}$ content of fermented tithonia. The results of the DMRT test showed that the CF content in the A2B1 treatment was significantly $(\mathrm{P}<0.05)$ higher than the A1B1, A1B2, A1B3, A2B2, A2B3 treatments. Table 1 shows that the lowest decrease in $\mathrm{CF}$ content was found in the A2B3 treatment (A. ficuum and incubation time of 7 days) of $16.52 \%$. The low content of CF in the A2B3 treatment was due to the A. ficuum producing cellulase enzymes. The cellulase enzymes could work optimally in reducing crude fiber content. Cellulase enzyme breaks beta-1,4 glycosidic bonds in cellulose, cyclodextrin, cellobiose, and other cellulose derivatives (Mingardon et al. 2011; Alami et al. 2017).

The longer the fermentation process, the lower the $\mathrm{CF}$ content; this is due to the increased opportunity for $A$. ficuum to degrade $\mathrm{CF}$ from the treatment substrate. Maulana (2019) reported that soy milk dregs fermented with A. ficuum could reduce CF content by up to $10.29 \%$. The content of CF is still high due to the short fermentation time; the microbes have not thrived and evenly, so the enzymes produced to degrade $\mathrm{CF}$ have not worked optimally in reducing the $\mathrm{CF}$ content.

\section{Phytase enzyme activity of fermented tithonia}

The phytase enzyme activity of fermented tithonia with different microbes and incubation time for each treatment is presented in Table 1.

The analysis of variance showed that there was an interaction $(\mathrm{P}<0.05)$ between the type of microbe and the length of incubation time on the activity of the fermented tithonia phytase enzyme. Factor A (type of microbe) and factor B (incubation time) also had a significant effect $(\mathrm{P}<0.05)$ on the activity of the fermented tithonia phytase enzyme. The results of the DMRT test showed that the movement of the phytase enzyme in the A2B3 treatment was significantly $(\mathrm{P}<0.05)$ higher than the other treatments. The increased activity of the phytase enzyme is due to $A$. ficuum reaching the optimum conditions for its growth, the better the development of the mold, the more enzymes produced, so that the enzyme activity will be higher. The lowest enzyme activity was found in the A1B3 treatment, this was due to cell death which resulted in decreased enzyme activity. After reaching the optimum point, microbial growth will slowly decrease because it begins to enter the death phase so that the activity of the phytase enzyme begins to fall.

According to Maryanti (2015), the growth phase begins with the lag phase (adaptation phase), where microbes adjust to changes in the media and their environment. The phase occurs shortly after inoculation, where the cells have not experienced growth, and the number is still relatively constant. Next is the log phase (growth phase). As the name implies, this phase is a phase of cell growth characterized by a significant increase in the number of cells because the cell division process occurs optimally. This phase is the best in determining the optimal time of inoculation of a cell. The third phase is the stationary phase, in which cells will no longer grow and remain relatively constant. The condition is due to reduced nutrients and increased waste in the growth medium. This phase continues until it enters the death phase, which means the number of cells decreases drastically. Cells begin to die because the concentration of nutrients is deficient and causes cell growth to be inhibited.

\section{Nutritional digestibility of fermented tithonia}

Digestibility of dry matter, organic matter, crude protein, and crude fiber from fermented tithonia are presented in Table 2.

The analysis of variance showed that fermented tithonia with different types of microbes and incubation time had no significant effect $(\mathrm{P}>0.05)$ on $\mathrm{DMD}$ of fermented tithonia. This is because the CF content of the treatment is relatively the same. Digestibility is closely related to the chemical composition of the material, especially the $\mathrm{CF}$ content. CF content in treatments A, B, C and D respectively $16.75 ; 16.52 ; 17.95$ and $17.37 \%$. The DMD 
value in each treatment ranged from 62.21 to 66.86. DMD is higher than the study of Susanti et al. (2020), where DMD in the combination of fermented tithonia and sugarcane shoots was 59.15\%, and Jamarun et al. (2019), which obtained DMD in fresh tithonia of $58.56 \%$.

The analysis of variance showed that tithonia fermentation with different types of microbes and incubation time gave no significant effect $(\mathrm{P}>0.05)$ on the OMD. The value of OMD in this study ranged from 66.03 to $67.36 \%$. This value is not much different from the DMD of fermented tithonia. The difference is not the OMD. After all, the OMD is very closely related to the DMD because some dry matter consists of organic matter. The OMD pattern followed the DMD pattern (Pazla et al. 2018a; Arief et al. 2021; Jamarun et al. 2021). The value of OMD in this study was higher than the study of Jamarun et al. (2019), which obtained a digestibility value of organic matter of $55.46 \%$ in tithonia without fermentation.

The analysis of variance showed that fermented tithonia with different types of microbes and incubation time had no significant effect $(\mathrm{P}>0.05)$ on the $\mathrm{CPD}$ of fermented tithonia. These results illustrate that the ability of rumen microbes to utilize protein is relatively the same. Besides, digestibility is closely related to the chemical composition of the ingredients. If the design in feed ingredients is relatively the same, the digestibility produced will also be pretty similar. The CPD material is also directly proportional to the crude protein content of the material in the feed.

In addition, another factor that caused the CPD not significantly different in the treatment was the crude fiber content of the material between treatments which was relatively the same. CPD values in this study ranged from 67.78 to 70.38 . This result is higher than the study of Susanti et al. (2020), which obtained a CPD value of $55.45 \%$ in the combination of sugarcane top and fermented tithonia.

The analysis of variance showed that fermented tithonia with different types of microbes and incubation time had a very significant effect $(\mathrm{P}<0.05)$ on the $\mathrm{CFD}$. DMRT further test results showed that treatment $\mathrm{A}$ was significantly different $(\mathrm{P}<0.05)$ with treatment $\mathrm{B}, \mathrm{C}$, and $\mathrm{D}$. Treatment $\mathrm{B}$ was quite different $(\mathrm{P}<0.05)$ with treatment $\mathrm{C}$ and $\mathrm{D}$. Treatment $\mathrm{C}$ was not quite different $(\mathrm{P}>0.05)$ with treatment $\mathrm{D}$. The average of CFD in this study ranged from 71.52-81.01\%. Fermentation in tithonia can increase CFD. It is because fermentation can stretch the bonds of fiber fraction components to make rumen microbes work more optimally.

The highest CFD value in this study was found in treatment $\mathrm{B}$, which was $81.01 \%$. The increase in CFD in treatment $\mathrm{B}$ was due to the crude fiber content of the material in treatment $\mathrm{B}$, which was lower than the other treatments with $16.52 \%$, so that rumen microbial activity in digesting crude fiber was more optimal. According to Yanti et al. (2021) and Jamarun et al. (2018), feed ingredients with low crude fiber will generally be easier to digest because microbes easily penetrate the cell walls of these materials. On the contrary, the higher the crude fiber content contained in a feed ingredient, the cell walls will be thicker and resistant to fiber-digesting microbes. It can result in a decrease in the digestibility of the feed ingredients. It can be seen from the lowest CFD found in treatment $\mathrm{C}(71.52 \%)$, with a crude fiber content of $17.95 \%$ higher than treatments $\mathrm{A}, \mathrm{B}$, and D.

\section{Rumen fluid characteristics of fermented tithonia}

Rumen fluid characteristics from fermented tithonia are presented in Table 3.

The analysis of variance showed that tithonia fermentation with different types of microbes and incubation time gave no significant effect $(\mathrm{P}>0.05)$ on the $\mathrm{pH}$ of the rumen fluid. The $\mathrm{pH}$ value of the rumen fluid in this study ranged from 6.72 to 6.85 , and the $\mathrm{pH}$ value was still in a condition that was quite optimal for rumen microbial growth. Jamarun and Zain (2013) stated that the optimal rumen $\mathrm{pH}$ for digestive activity in the rumen ranged from 6.0 to 7.0. Rumen fluid $\mathrm{pH}$ less than 6.0 or above 7.0 can inhibit rumen microbial activity so that the ability to degrade feed decreases.

Changes in rumen $\mathrm{pH}$ related to the production of volatile fatty acid (VFA) produced in Table 3 show that the higher the production of VFA produced, the lower the rumen $\mathrm{pH}$. VFAs contain organic acids such as acetic, propionate, butyrate, which make the atmosphere in the rumen acidic. Bhatia and Yang (2017) stated that the higher the value of VFA, the more other organic acids (acetic, propionic, butyric, isobutyrate, and isovalerate) were produced the $\mathrm{pH}$ of the rumen fluid would below. However, based on the results, the rumen $\mathrm{pH}$ was not significantly different from each treatment A, B, C, and D. It was influenced by the provision of Mc Dougall buffer (artificial saliva), which played a role in maintaining $\mathrm{pH}$. According to Van Soest et al. (1991), the condition of rumen $\mathrm{pH}$ remains constant due to the buffering capacity from saliva because it contains a lot of bicarbonate and phosphate and the absorption system of VFA through the rumen wall.

The degree of acidity in the rumen is affected by the type of feed given but generally remains at a constant $\mathrm{pH}$. Stable rumen $\mathrm{pH}$ in this study created a familiar atmosphere in the rumen and is suitable for rumen microbes in carrying out their activities. Jamarun et al. (2017c) stated that rumen environmental conditions have a close relationship with the $\mathrm{pH}$ of the rumen fluid because the high and low $\mathrm{pH}$ in the rumen will affect the rumen microbial activity.

The analysis of variance showed that tithonia fermentation with different types of microbes and incubation time gave no significant effect $(\mathrm{P}>0.05)$ on the production of rumen fluid VFA. It indicated that feed fermentation using L. plantarum and A. ficuum did not affect rumen microbial activity in producing VFA in the form of acetic acid, propionic acid, and butyric acid. The production of VFA in this study ranged from $116.67 \mathrm{mM}-$ $135 \mathrm{mM}$; this value was still in the range of VFA concentrations under normal conditions. McDonald et al. (2010) stated that the normal range for total VFA was 70$150 \mathrm{mM}$. 
Table 6. Digestibility of dry matter, organic matter, crude protein, and crude fiber from fermented tithonia

\begin{tabular}{ccccc}
\hline \multirow{2}{*}{ Treatments } & \multicolumn{4}{c}{ Nutritional digestibility (\%) } \\
\cline { 2 - 5 } & $\begin{array}{c}\text { Dry } \\
\text { matter }\end{array}$ & $\begin{array}{c}\text { Organic } \\
\text { matter }\end{array}$ & $\begin{array}{c}\text { Crude } \\
\text { Protein }\end{array}$ & $\begin{array}{c}\text { Crude } \\
\text { fiber }\end{array}$ \\
\hline $\mathrm{A}$ & 65.73 & 66.22 & 69.70 & $78.11^{\mathrm{b}}$ \\
$\mathrm{B}$ & 66.86 & 67.36 & 71.50 & $81.01^{\mathrm{a}}$ \\
$\mathrm{C}$ & 62.21 & 66.03 & 69.57 & $71.52^{\mathrm{c}}$ \\
$\mathrm{D}$ & 66.01 & 66.69 & 67.78 & $73.79^{\mathrm{c}}$ \\
$\mathrm{SE}$ & 0.32 & 0.36 & 0.62 & 0.69 \\
\hline Note: & Different & superscripts in the & same column show
\end{tabular}

significantly different effects $(\mathrm{P}<0.05)$

Table 7. Rumen fluid characteristics from fermented tithonia

\begin{tabular}{cccc}
\hline \multirow{2}{*}{ Treatments } & \multicolumn{3}{c}{ Rumen fluid characteristics } \\
\cline { 2 - 4 } & $\mathbf{p H}$ & $\mathbf{V F A}(\mathbf{m M})$ & $\mathbf{N H}_{\mathbf{3}}(\mathbf{m g} / \mathbf{1 0 0 m l})$ \\
\hline $\mathrm{A}$ & 6.79 & 130 & $12.18^{\mathrm{ab}}$ \\
$\mathrm{B}$ & 6.72 & 135 & $14.31^{\mathrm{a}}$ \\
$\mathrm{C}$ & 6.85 & 116.67 & $10,48^{\mathrm{b}}$ \\
$\mathrm{D}$ & 6.83 & 123.33 & $9.21^{\mathrm{b}}$ \\
SE & 0.03 & 6.96 & 0.86 \\
\hline
\end{tabular}

Note: Different superscripts in the same column show very significant different effects $(\mathrm{P}<0.05)$

The insignificant difference in VFA production was also due to the relatively similar composition, feeding level, and physical form of the feed. Storm and Kristensen (2010) stated that the design of VFA in the rumen changes with differences in physical form, feed composition, level and frequency of feeding, and processing. High or low VFA production can be used as a measure of the fermentability of a feed ingredient. Jones and Murphy (1989) stated that the higher the fermentability level of the feed, the greater the VFA produced.

The analysis of variance showed that tithonia fermentation with different types of microbes and incubation time had a significantly different effect $(\mathrm{P}<0.05)$ on the production of rumen fluid $\mathrm{NH}_{3}$. The results of the DMRT further test showed that treatment A was not significantly different $(\mathrm{P}>0.05)$ from treatments $\mathrm{B}, \mathrm{C}$, and D. However, Treatment B showed a significant difference $(\mathrm{P}<0.05)$ with treatments $\mathrm{C}$ and $\mathrm{D}$. Also, treatment $\mathrm{C}$ showed the effect was not significantly different from treatment D.

The highest $\mathrm{NH}_{3}$ production was found in treatment $\mathrm{B}$, namely, $14.31 \mathrm{mg} / 100 \mathrm{ml}$. The high output of $\mathrm{NH}_{3}$ in treatment $\mathrm{B}$ indicated that the rumen microbial activity was running well. $\mathrm{NH}_{3}$ concentration means the fermentability of feed related to protein digestibility, rumen microbial activity, and microbial population (Pazla et al. 2018b). In addition, the high production of $\mathrm{NH}_{3}$ in treatment $\mathrm{B}$ was due to the increased degradation of crude protein in the rumen. $\mathrm{NH}_{3}$ concentration was strongly influenced by protein solubility. The more soluble the protein, the easier it will be for rumen microbes to degrade it; the CPD indicates this in treatment $\mathrm{B}$, which was higher than in other treatments (Table 2). It is following the opinion of Bannink et al. (2016), which states that. The higher the degradation of $\mathrm{CP}$ in the rumen will increase the concentration of $\mathrm{NH}_{3}$ and vice versa

The lowest $\mathrm{NH}_{3}$ concentration was found in treatment $\mathrm{D}$, which was 9.21. The low concentration of $\mathrm{NH}_{3}$ in treatment $\mathrm{D}$ was due to the low availability of $\mathrm{N}$ in the feed; this was indicated by the low crude protein content of the material, which was 27.56. Mayulu (2014) and Wulandari et al. (2017) stated that the lower the crude protein content of the ration, the production of $\mathrm{NH}_{3}$ would also decrease. The $\mathrm{NH}_{3}$ production produced in each treatment in this study ranged from 9.21 to 14.31 . This value is still in the normal range for rumen microbial activity and growth. The opinion of Satter and Slyter (1973) stated that the minimum concentration of ammonia required for microbial protein synthesis is $5 \mathrm{mg} / 100 \mathrm{ml}$ rumen fluid. The study concluded that fermented tithonia using A. ficuum with an incubation period of 7 days improve the quality of tithonia. It is seen from the content of CP $(31.02 \%)$, CF $(16.52 \%)$, phytase enzyme activity (37.36 U/ml), DMD (66.86\%), OMD (67.36\%), CFD (81.01\%), CPD (70.37\%), VFA production $135 \mathrm{mM}$ and $\mathrm{NH}_{3}$ concentration $14.31 \mathrm{mg} / 100 \mathrm{ml}$, and $\mathrm{pH}$ value 6.72 which is very suitable for rumen microbial growth.

\section{ACKNOWLEDGEMENTS}

Thank you to the Indonesian Ministry of Research and Technology/ National Research and Innovation Agency for funding this research with contract number 266/SP2H/LT/DPRM/2021.

\section{REFERENCES}

Alami NH, Kuswytasari ND, Zulaika E, Shovitri M. 2017. Optimization of cellulase production by candida G3. 2 from the rhizosphere of Gunung Anyar mangrove, Surabaya. Proc Intl Conf Green Technol 8: $399-406$.

AOAC. 2010. Official Methods of Analysis. Association of Analytical Chemists, Arlington, Virginia, USA.

Arief, Rusdimansyah, Sowmen S, Pazla R, Rizqan. 2020. Milk production and quality of Etawa crossbred dairy goat that given Tithonia diversifolia, corn waste and concentrates based palm Kernel cake. Biodiversitas 21 (9): 4004-4009. DOI: 10.13057/biodiv/d210910

Arief, Simel S, Rusdimansyah, Pazla R. 2019. Ration digestibility based on palm oil industry by products, tithonia (Tithonia diversifolia) and corn waste for Etawa crossbred dairy goat. Pak J Nutr 18 (8): 733738. DOI: $10.3923 /$ pjn.2019.733.738

Arief, Jamarun N, Satria B, Pazla R. 2021. Milk quality of Etawa dairy goat fed palm kernel cake, tithonia (Tithonia diversifolia), and Sweet potato leaves (Ipomoea batatas L). IOP Conf Ser Earth Environ Sci 709 (1): 012023. DOI: 10.1088/1755-1315/709/1/012023.

Aye PA. 2016. Comparative nutritive value of Moringa oleifera, Tithonia diversifolia, and Gmelina arborea leaf meals. Am J Food Nutr 6 (1): 23-32.

Bannink A, Henk J, Van L, Jennifer L, Ellis, James F. 2016. The contribution of mathematical modeling to understanding dynamic aspects of rumen metabolism. Front Microbiol 7: 1-16. DOI: 10.3389/fmicb.2016.01820.

Bhatia KS, Yang HY. 2017. Reviews: Microbial production of volatile fatty acids: current status and future perspectives. Environ Sci Bio/Technol. DOI: 10.1007/s11157-017-9431-4.

Hafis A. 2019. Produksi titonia (Tithonia diversifolia) sebagai pakan hijauan dengan jenis pupuk berbeda pada tanah ultisol. [Thesis]. Fakultas Peternakan Universitas Andalas, Padang. [Indonesian] 
Jamarun N, Agustin F, Pazla R, Oktiacahyani N. 2017b. Effects of phosphor $(\mathrm{P})$ supplementation in combination with calcium $(\mathrm{Ca})$ and manganese (Mn) during oil palm frond fermentation by Phanerochaete chrysosporium on fiber fractions content. In Proceedings of The 5th International Seminar of Animal Nutrition and Feed Sciences, Mataram: Indonesian Association of Nutrition And Feed Scientist. [Indonesian]

Jamarun N, Elihasridas, Pazla R, Fitriyani. 2017a. In vitro nutrients digestibility of the combination tithonia (Tithonia Diversifolia) and Napier Grass (Pennisetum purpureum). In The $7^{\text {th }}$ International Seminar on Tropical Animal Production, Yogyakarta. [Indonesian]

Jamarun N, Pazla R, Yanti G. 2021. Effect of boiling on in-vitro nutrients digestibility, rumen fluid characteristics, and tannin content of mangrove (Avicennia marina) leaves as animal feed. Intl Conf Green Agro-Ind Bioecon. DOI: 10.1088/1755-1315/733/1/012106

Jamarun N, Pazla R, Zain M, and Arief. 2019. Comparison of in vitro digestibility and rumen fluid characteristics between the tithonia (Tithonia diversifolia) with elephant grass (Pennisetum purpureum). International Conference on Animal Production for Food Sustainability. IOP Conf Ser Earth Environ Sci 287: 1-5. DOI: 10.1088/1755-1315/287/1/012019.

Jamarun N, Zain. M. 2013. Dasar Nutrisi Ruminansia. Jasa Surya Press, Padang. [Indonesian]

Jamarun N, Zain M, Arief, Pazla R. 2017c. Effects of calcium (Ca), phosphorus $(\mathrm{P})$, and manganese $(\mathrm{Mn})$ supplementation during oil palm frond fermentation by Phanerochaete chrysosporium on rumen fluid characteristics and microbial protein synthesis. Pak J Nutr 16 (6): 393-399. DOI: 10.3923/pjn.2017.393.399.

Jamarun N, Zain M, Arief, Pazla R. 2018. Populations of rumen microbes and the in vitro digestibility of fermented oil palm fronds in combination with tithonia (Tithonia diversifolia) and elephant grass (Pennisetum purpureum). Pak J Nutr 17 (1): 39-45. DOI: 10.3923/pjn.2018.39.45

Jones S, Murphy MR. 1989. Production of volatile fatty acids in the rumen and cecum-colon of steers as affected by forage : concentrate and forage physical form. J Dairy Sci 72 (2): 485-492. DOI: 10.3168/jds.S0022-0302(89)79130-X.

Maryanti T. 2015. Isolasi dan karakteristik kapang endofit dari ranting tanaman parijoto (Medinilla speciosa Reinw. Ex Blume) dan uji aktifitasnya sebagai antibakteri. [Thesis]. UIN Syarif Hidayatullah, Jakarta. [Indonesian]

Maulana Z. 2019. Pengaruh dosis inoculum Aspergillus ficuum dan lama fermentasi terhadap aktifitas selulase, serat kasar dan daya cerna serat kasar ampas susu kedelai fermentasi. [Thesis]. Universitas Andalas, Padang. [Indonesian]

Mayulu H. 2014. The nutrient digestibility of local sheep fed with amofer palm oil byproduct-based complete feed. Int J Sci Eng 7: 106-111. DOI: $10.12777 /$ ijse.7.2.106-112.

McDonald P, Edwards R, Greenhalg JFD, Morgan CA. 2010. Anima nutrition. Pearson Education Limited, England.

Mingardon F, Bagert JD, Maisonnier C, Devin L. Trudeau, Frances H. A 2011. Comparison of family 9 cellulases from mesophilic and thermophilic bacteria. Appl Environ Microbiol 77 (4): 1436-1442. DOI: 10.1128/AEM.01802-10.

Mirnawati, Djulardi A, Marlida Y. 2013. Improving the quality of palm kernel cake through fermentation by Eupenicillium javanicum as poultry ration. Pak J Nutr 12 (12): 1085-1088. DOI: 10.3923/pjn.2013.1085.1088.

Mirnawati, Rizal Y, Marlida Y, Kompiang PI. 2010. The role of humic acid in palm kernel cake fermented by Aspergillus niger for poultry ration. Pak J Nutr 9 (2): 182-185. DOI: 10.3923/pjn.2010.182.185.
Oluwasola TA, Dairo FAS. 2016. Proximate composition, amino acid profile, and some anti-nutrients of Tithonia diversifolia cut at two different times. Afr J Agric Res 11 (38): 3659-363. DOI: 10.5897/AJAR2016.10910

Pazla R, Jamarun N, Zain M, Arief. 2018b. Microbial protein synthesis and in vitro fermentability of fermented oil palm fronds by Phanerochaete chrysosporium in combination with tithonia (Tithonia diversifolia) and elephant grass (Pennisetum purpureum). Pak J Nutr 17 (10): 462-470. DOI: 10.3923/pjn.2018.462.470.

Pazla R, Zain M, Ryanto I, Dona A. 2018a. Supplementation of minerals (phosphorus and sulfur) and Saccharomyces cerevisiae in a sheep diet based on a cocoa by-product. Pak J Nutr 17 (7): 329-335. DOI: 10.3923/pjn.2018.329.335.

Putra AYT, Rosida, Azmir K. 2019. Chemical and sensory characteristics of sorghum (Sorghum bicolor) tapai with traditional packaging. Food ScienTech J 1 (2): 92-99. DOI: 10.33512/fsj.v1i2.7096.

Satter LD, Slyter LL. 1973. Effect of ammonia concentration on rumen microbial protein production in vitro. Br J Nutr 32: 199-207. DOI: 10.1079/BJN19740073.

Saylor BA, Casale F. 2020. Effect of microbial inoculation and particle size on fermentation profile, aerobic stability, and ruminal in situ starch degradation of high-moisture corn ensiled for a short period. J Dairy Sci 103 (1): 1-16. DOI: 10.3168/jds.2019-16831.

Selle PH, Ravindran P, Caldwell RA, Bryden WL. 2021. Phytate and phytase : consequences for protein utilisation. Nutr Res Rev 13 (2): 255-278. DOI: 10.1079/095442200108729098

Shieh TR, Ware JH. 1968. Survey of microorganisms for the production of extracellular phytase. Appl Microbiol 16 (9): 1348-1351. DOI: 10.1128/am.16.9.1348-1351.1968

Steel RGD, Torrie JH. 2002. Principle and Procedures of Statistics: A Biometrical Approach. 3rd ed. McGraw Hill Book, New York.

Storm AC, Kristensen NB. 2010. Effects of particle size and dry matter content of a total mixed ration on intraruminal equilibration and net portal flux of volatile fatty acids in lactating dairy cows. J Dairy Sci 93 (9): 4223-4238. DOI: 10.3168/jds.2009-3002.

Sumenger M, Dincer S, Kaya A. 2013. Production and characterization of phytase from Lactobacillus plantarum. Food Biotechnol 27 (2): 105 118. DOI: $10.1080 / 08905436.2013 .781507$.

Susana IWR, Tangenjaya B, Hastiono S. 2000. Seleksi kapang penghasil enzim fitase. Jurnal Ilmu Ternak dan Veteriner 5 (1): 1-6. [Indonesian]

Susanti D, Jamarun N, Agustin A, Astuti A, Yanti G. 2020. Kecernaan invitro fraksi serat kombinasi pucuk tebu dan titonia fermentasi sebagai pakan ruminansia. Agripett 20: 86-95. DOI: 10.17969/agripet.v20i1.16040. [Indonesian]

Tilley JMA, Terry RA. 1963. A two-stage technique for the in vitro digestion of forage crops. J Brit Grassland Soc 18: 104-111. DOI: 10.1111/j.1365-2494.1963.tb00335.x.

Van Soest PJ, Robertson JB, Lewis BA. 1991. Methods for dietary fiber, neutral detergent fiber, and nonstarch polysaccharides in relation to animal nutrition. J Dairy Sci 74 (10): 3583-3597. DOI: 10.3168/jds.S0022-0302(91)78551-2.

Wulandari, Budi PW, Cuk TN, Ali A. 2017. In vitro degradation and rumen fermentation characteristics of soybean meal protected with different levels of formaldehyde. in The 7th International Seminar on Tropical Animal Production, Yogyakarta. [Indonesian]

Yanti G, Jamarun N, Elihasridas, Astuti T. 2021. Quality improvement of sugarcane top as an animal feed with biodelignification by Phanerochaete chrysosporium fungi on in-vitro digestibility. In ICOMSET2020. DOI: 10.1088/1742-6596/1940/1/012063. 